\title{
Starfish Dermatitis Due \\ to Marthasterias Glacialis
}

\section{Dermatite da Estrela-do-Mar Induzida pela Marthasterias Glacialis}

André Ribeiro¹, Barbara Oliveira², Helena Melo³ ${ }^{3}$ Miguel Correia ${ }^{3}$, João Maia Silva³,4

\begin{abstract}
Some marine organisms are known to inflict contact dermatitis, whether secondary to professional or recreational activities. We report a 23-year-old white woman with hypersensitivity reaction induced by Marthasterias glacialis starfish. To our knowledge this is the first report of starfish hypersensitivity reaction induced by Marthasterias glacialis on human skin. Because of the growing popularity of recreational subaquatic activities, such as scuba diving, reports about diving-related skin diseases are expected to increase.

KEYWORDS: Contact Dermatitis; Marthasterias Glacialis; Starfish

\section{RESUMO}

Alguns organismos marinhos podem causar eczemas de contacto, sejam secundários a atividades profissionais ou recreativas. Apresentamos uma mulher de 23 anos com reação de hipersensibilidade induzida pela estrela-do-mar Marthasterias glacialis. Do nosso conhecimento, este é o primeiro relato da reação de hipersensibilidade da estrela-do-mar induzida por Marthasterias glacialis na pele humana. Devido à crescente popularidade de atividades subaquáticas recreativas, os relatórios sobre doenças de pele relacionadas com o mergulho podem aumentar.
\end{abstract}

PALAVRAS-CHAVE: Dermatite; Estrela-do-Mar; Marthasterias Glacialis 


\section{INTRODUCTION}

Some marine organisms are known to inflict contact dermatitis, whether secondary to professional or recreational activities. With the increasing practice of the subaquatic recreational activities, the number of related dermatitis tends to increase. There are reports of dermatitis to several marine organisms, such as sea anemone, ${ }^{1}$ marine sponges, ${ }^{2}$ jellyfish, ${ }^{3}$ coral, ${ }^{4}$ and mucilaginous aggregates. ${ }^{5}$ Starfish, namely the Acanthaster planci starfish, known as "crown of thorns", was also reported to inflict skin reactions. However, its toxicity is not hypersensitivity mediated but is caused by a venom in its fragile spines, that can cause not only topical injuries, but also serious systemic symptoms. ${ }^{6}$ We thereby present to our knowledge the first report of starfish hypersensitivity reaction induced by Marthasterias glacialis on human skin.

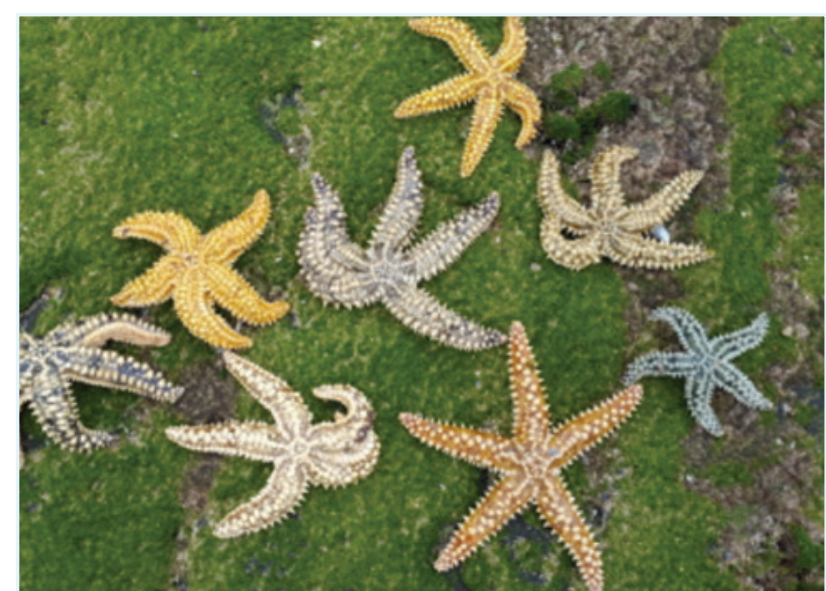

FIGURE 1. Marthasterias glacialis starfish in its natural environment.

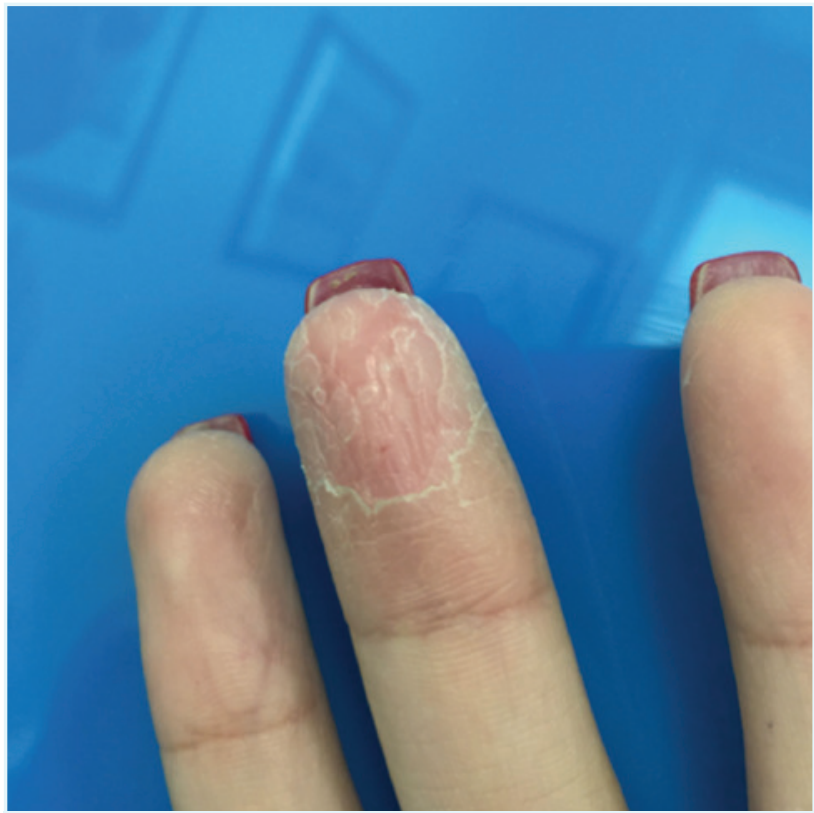

FIGURE 2. Clinical photos showing fissured digital pulpitis in the first, third and fourth fingers of the right hand.

\section{CASE REPORT}

We report a 23-year-old white woman, a researcher studying the dynamics of coelomocytes during Marthasterias glacialis starfish regeneration. To accomplish the different goals of her study, she had frequent contact with Marthasterias glacialis (Fig. 1) even if she reported to wear gloves. Over time, she started reporting a painful bilateral digital pulpitis. These signs were mitigated after starfish contact eviction. After the frequent symptoms appearance and the possible relation with Marthasterias glacialis contact, she started to wear 2 pairs of gloves with different composition, such as nitrile and latex. During a period of more frequent contact with the starfish, she developed a painful and fissured digital pulpitis, more intense in the first, third and fourth fingers of the right hand (Fig. 2) that brought her to our attention. Other symptoms were denied. She was previously healthy, had no personal or familiar history of allergy or atopy and wasn't under any chronic or new medication. Epicutaneous patch tests were performed and the following series were tested: standard series of the Portuguese Contact Dermatitis Study Group (32 allergens); patient's personal products such as water from the starfish tank, a $4 \mathrm{~mm}$ tip of the arm of the starfish, anaesthesia plus asterosaponin, starfish coelomic fluid, nitrile glove impregnated with tank water, and dry nitrile glove. The patches were detached at 48 hours and the results interpreted at 72 hours. An extreme positive allergic reaction $(+++)$ with erythema, infiltration and bullous reaction was induced by the arm of the starfish (Fig. 3). Mild positive reactions (+) were observed to nickel sulfate and perfume mixture. The patient started clo-

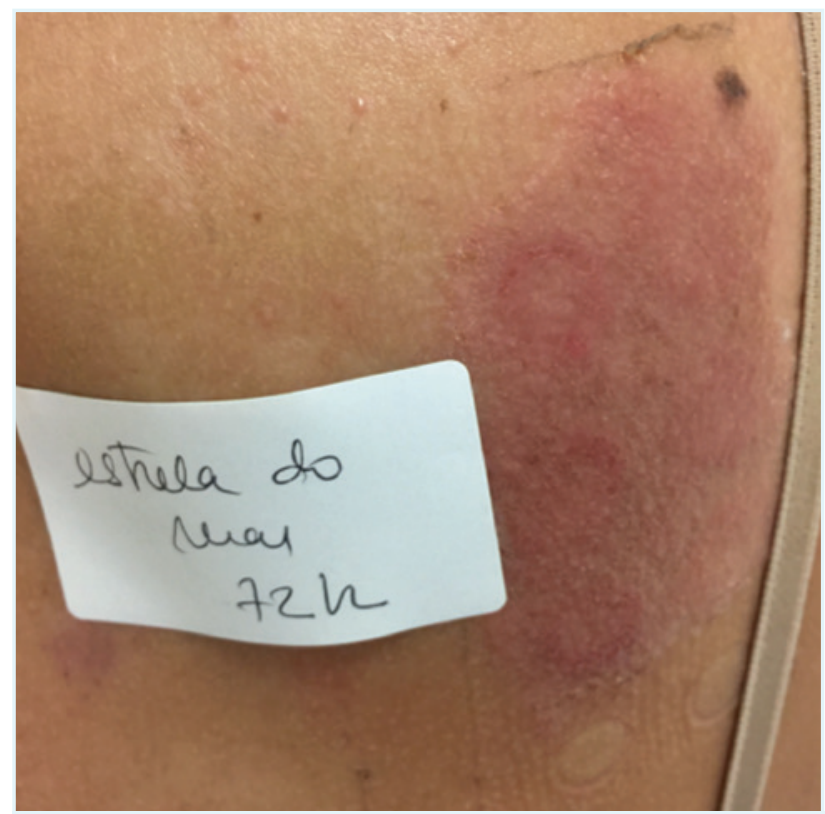

FIGURE 3. Patch test results showing positive allergic reaction $(+++)$ with erythema, infiltration and bullous reaction induced by the arm of the starfish after 72 hours. 
betasol 0.1\% cream twice daily and desloratadine $5 \mathrm{mg}$ once per day po. Concomitantly, the patient received instructions to avoid direct contact with the starfish. Two weeks after the beginning of therapy, the patient had almost fully recovered from her lesions. One month later, complete remission was obtained.

\section{DISCUSSION}

Starfishes, who belong to Asteroidea class of Echinodermata phylum, are dorsoventrally flattened with five to fifty rays projecting from a central disk.7 Marthasterias glacialis is the most seen starfish species in Portugal coast. M. glacialis is a major predator of marine animals with mussels being the preferred prey. This starfish species can attain $70 \mathrm{~cm}$ in diameter, however is commonly found with $25-30 \mathrm{~cm}$. Each arm bears three longitudinal rows of spike-like spines surrounded by large cushions of pedicellariae with smaller spines scattered between these rows. ${ }^{8}$

Marine organisms resulted from adaptation of different environment conditions. In the sea, where there is almost no light, visual communication is disadvantageous. Organisms were forced to evolve other means of communication, e.g. chemical communication. Echinodermata, for instance, are known for the synthesis of some toxic compounds, named saponins (steroidal glycosides). Cytotoxic, hemolytic activity and repellant activity to other marine organisms have been observed, as well as antimicrobial, antiviral activities and anti-inflammatory effects. $^{8}$ The asterosaponins spread inside the water, where many animals are present, so that contact with the surrounding water can induce a pruriginous, papulo-urticarial eruption.?

Some species are venomous. For example, the Acanthaster planci starfish, known as "crown of thorns", can inflict a painful sting which may result in granulomatous lesions. This species is the only who has a toxin in its spines that can cause not only topical injuries, but also serious systemic symptoms. ${ }^{6}$ Other member of Echinodermata phylum, such as sea urchins and sea cucumbers, also produce venoms. While sea urchins produce toxins present in pedicilariae that can harm nervous or circulatory systems, sea cucumbers do not have spines, although they produce holothurin, a visceral toxin that irritates the skin and mucous membranes. ${ }^{10,11}$

It has therefore been assumed that Echinodermata envenomation reactions are generally toxic rather than allergic. In the current case, skin lesions were clinically suggestive of an allergic contact dermatitis, and type IV hypersensitivity was confirmed using epicutaneous patch tests. Starfish arm tip was confirmed as the causative agent while any water-soluble allergen from the starfish tank, or from the coelomic fluid were excluded.

There have been several reports of delayed, recurrent, persistent skin reactions that have been attributed to allergies with other marine species. ${ }^{1-6}$ In additional to type I hypersensitivity, type IV allergy is considered to be involved in such eruptions. Addy et al showed coral dermatitis to be an allergic contact dermatitis because not all people who have contact with coral actually develop the dermatitis. ${ }^{12}$ That study suggested some of the risk factors for coral dermatitis are seafood allergy and atopic dermatitis. In our case there was no identified risk factor such as atopic dermatitis or any known allergy.

In the management of Marthasterias glacialis contact dermatitis, specific recommendations are required, taking into account the environment and specific conditions of the patient. Contact eviction is the main form of management. In this case, the patient used different types of gloves without relevant effect. The treatment after contact should be symptomatic, and topical steroids may afford symptomatic relief.

This case is also particular because it results from a professional and recurrent contact. Although this type of exposition is unlikely to occur in the wild, allergic contact dermatitis must be considered. Patch tests can be useful in the study of contact dermatitis induced by Asteroidea class, namely starfishes.

CONFLICTS OF INTEREST: The authors declare that they have no conflicts of interest.

FINANCIAL SUPPORT: This work has not received any contribution, grant or scholarship.

CONFIDENTIALITY OF DATA: The authors declare that they have followed the protocols of their work center on the publication of data from patients.

PROTECTION OF HUMAN AND ANIMAL SUBJECTS: The authors declare that the procedures followed were in accordance with the regulations of the relevant clinical research ethics committee and with those of the Code of Ethics of the World Medical Association (Declaration of Helsinki).

CONFLITOS DE INTERESSE: Os autores declaram não ter qualquer conflito de interesse na realização do presente trabalho.

FONTES DE FINANCIAMENTO: Não houve qualquer fonte de financiamento na realização do presente trabalho. 
CONFIDENCIALIDADE DOS DADOS: Os autores declaram ter seguido os protocolos da sua instituição acerca da publicação dos dados de doentes.

PROTEÇÃO DE PESSOAS E ANIMAIS: Os autores declaram que os procedimentos seguidos na elaboração do presente trabalho estão em conformidade com as normas das comissões de investigação clínica e de ética, bem como da declaração de Helsínquia e da Associação Médica Mundial.

\section{REFERENCES}

1. Uva L, Miguel D, Ferreira J, Lopes L, Filipe P. A case of sea anemone dermatitis caused by Alicia mirabilis. Dermatitis. 2013;24:95. doi: 10.1097/DER.0b013e31827b14f8.

2. Ashworth J, Curry FM, White IR, Rycroft RJ. Occupational allergic contact dermatitis in east coast of England fishermen: newly described hypersensitivities to marine organisms. Contact Dermatitis. 1990;22:185-6.

3. Kokelj F, Del Negro P, Montanari G. Jellyfish dermatitis due to Carybdea marsupialis. Contact Dermatitis. 1992;27:195.

4. Tong D. Coral dermatitis in the aquarium industry. Contact Dermatitis. 1995;33:207-8.

5. Kokelj F, Trevisan G, Stinco G, Piscanc AM. Skin damage caused by mucilaginous aggregates in the Adriatic sea. Contact Dermatitis. 1994;31:257-9.

6. Sato H, Tsuruta Y, Yamamoto Y, Asato Y, Taira K, Hagiwara K, et al. Case of skin injuries due to stings by crown-of-thorns starfish (Acanthaster planci). J Dermatol. 2008;35:162-7.

7. Mah CL, Blake DB. Global diversity and phylogeny of the Asteroidea (Echinodermata). PLoS One. 2012;7:e35644. doi: 10.1371/journal.pone.0035644.

8. Franco C. Proteomics based approach to understand tissue regeneration [Dissertation in Biochemistry]. Oeiras: Instituto de Tecnologia Química e Biológica, Universidade Nova de Lisboa; 2011.

9. Kanerva L, Elsner P, Wahlberg JE, Maibach HI. Handbook of Occupational Dermatology. Berlin: Springer; 2000.

10. Haddad V Jr. Environmental dermatology: skin manifestations of injuries caused by invertebrate aquatic animals. An Bras Dermatol. 2013;88:496-506. doi: 10.1590/abd18064841.20132587.

11. Haddad V Jr, Lupi O, Lonza JP, Tyring SK. Tropical dermatology: marine and aquatic dermatology. J Am Acad Dermatol. 2009;61:733-50; quiz 751-2.

12. Addy JH. Red sea coral contact dermatitis. Int J Dermatol. 1991;30:271-3 